\title{
The relationship between Unions and Innovation in Chile
}

\author{
Goretti Cabaleiro ${ }^{1}$, Francisca Gutiérrez ${ }^{2 *}$
}

\begin{abstract}
This article examines how and to what extent unions affect companies' innovation in Chile. It contributes to the existing literature in the following two aspects: First, because it widens the scope of analysis focusing in a developing country that is characterized by some specificities regarding the innovation as well the union landscape. Second, because it provides more in-depth analysis, taking into account the effect of unions on the four different types of innovation proposed in the Oslo Manual by OECD. Results show that unions do not affect product and process innovation while influence organizational innovation and marketing in a non-linear way
\end{abstract}

Keywords: Labor unions, Trade unions, Innovation, Chile.

Submitted: March $28^{\text {th }}, 2019 /$ Approved: October $22^{\text {nd }}, 2019$

\section{Introduction}

Innovation is nowadays widely recognized as a central driver of economic growth and development for companies and countries. In consequence, many companies and many governments are putting innovation at the center of their strategies leading and motivating research to understand better what is innovation and what determines and fosters it. For this purpose, in the last decades, innovation has been defined and analyzed at the firm as well as the systemic level, though most of the studies take place in developed countries and on the manufacturing and the high technology industries (Geldes et al $.2017 \mathrm{~b}$ ). Moreover, previous studies have used different definitions, classifications, and types of innovation, leading to some confusion in the field. In this context, OECD reached consensus when proposing an innovation's classification in the Oslo Manual. Specifically, this manual considers the following definition: "innovation is the implementation of a new or significantly improved product (good or service), of a process, marketing method, or a new organizational method in business practices, workplace organization or external relations" (OECD, 2006, p. 56). This definition introduced four different types of innovation: product innovation, process innovation, marketing innovation, and organizational innovation. Where product innovation and process innovation are closely related to the concept of technological developments, marketing innovations are strongly related to pricing strategies, product package design, product placement, and promotion activities, and, finally, organizational innovations are strongly related to the business practices. After the acceptance of this definition, the Global Innovation Index (GII) was created in 2007 to provide a framework to measure innovation. In particular, this index is evolving in each edition, aiming to capture the multi-dimensional facets of innovation by providing a rich database of detailed metrics for 126 economies. However, even though this index contemplates so many metrics that influence innovation, there are still variables that are not considered and have not received the merited attention. From our point of view, this is the case of the unions. Specifically, the omission of this variable in the GII and its scarce attention by the academic community ${ }^{1}$, may undermine the private and public initiatives that draw on these analyses to promote innovation, especially in companies or countries with high union density or union participation.

There is evidence that shows unions can have a significant impact on innovation; however, if its impact is positive or negative is still a matter of discussion. On the one hand, some studies argue that unions may affect the ability of companies to innovate, basically because they reduce the control over the workplace, and increase the cost of labor limiting so the resources available to innovate. On the other hand, studies state that unions can have a positive effect because they force or persuade companies to compete based on innovation instead of competing based on low cost.

This article examines how and to what extent unions affect companies' innovation in Chile and contributes to the existing literature in the following two aspects: First, because it widens the scope of analysis focusing in a developing country that is characterized by some specificities regarding the innovation as well the union landscape. Regarding innovation, as Geldes \& Felzensztein, (2013) and Geldes et al. (2017b) show, Chile shares common problems related to innovation with other Latin American and emerging countries as the late adaptation of innovation, the effects of exogenous technological change, informality on the process of innovation, an adaptive and incremental nature of innovation, the lack of coordination with the national innovation and middle and lower levels of social capital that implies some difficulties to the formation of innovation networks. Regarding unions, Chile is characterized because 1) Union density is higher than in the US (where most of the studies have taken place $)^{2}, 2$ ) Chile presents a slight growth in this indicator since 2000 (while in Europe and the US this indicator has decreased over the last decade) $)^{3}$. This increase has been interpreted as

\footnotetext{
${ }^{1}$ For instance, in Web of Science, only 3 of the 2434 papers that are focused on "product innovation", also refer to "unions"

${ }^{2}$ According to the ILOSTAT, in 2016, the union density attained 10.3\% in the US, while 19.6\% in Chile. The database is available at https://www.ilo.org/ilostat/. Consulted 25 March 2019 ${ }^{3}$ In 2000, Chile registered a union density of 14,8\% while in 2016 this number attaint the 19,6\% (Dirección del Trabajo, 2016b)
}

1) School of Economics \& Business, Universidad de Navarra

2) Facultad de Economía y Negocios, Universidad Alberto Hurtado

*Corresponding author: fgutierrez@uahurtado.cl 
a sign of the generational turnover and the reactivation of social protest in the country (Observatorio de Huelgas Laborales, 2018), and 3) unions still play a political role in Chile. Historically, Latin-American unions have been tightly related to left-wing political parties and have actively engaged in the political arena, which has not been the case in the United States (Murillo, 2001). Although Chilean unions' ties with political parties have debilitated in the last two decades as part of the neoliberal turn (Zapata, 2001), unions still addressee a lot of their time to influencing political decisions. In this sense, unions can be vital to developing innovation policies. Second, our study takes into account the impact of unions on the different types of innovation defined by the Oslo Manual in 2007. Most of the studies regarding the impact of unions on innovation have considered $R \& D$ expenditures as a measure of firm innovation activity. However, as not all R\&D investment leads to innovation, it also has been acknowledged that this input measure cannot correctly represent innovation output. To avoid this and adhere to the definition of innovation, this paper will analyze the effect of unions in the different types of innovation, that is, in 1) innovation process, 2) innovation in marketing, 3) organizational innovation, and 4) product innovation.

The paper is organized as follows. Section 2 presents the literature review and develop competing hypotheses. Section 3 provides an overview of the history and legal frame of unions in Chile. Section 4 describes the sample, variables, and methodology. Section 5 presents the main statistics descriptive, and the results, and Section 6 concludes and discusses the results.

\section{Literature Review and Hypotheses Development}

Empirical research has not been conclusive regarding the extent nor the direction of the unions' influence on innovation. Existing results have shown opposite results depending on the context and strategy of analysis. Expressly, U.S studies from 2010 onwards mainly agree that unions negatively affect innovation. For instance, Angus, Cozzi, and Furukawa (2016) find that an increase in the bargaining power of wage-oriented unionism leads to a decrease in $\mathrm{R} \& \mathrm{D}$ expenditures in the UK and the US. In the same line, Bradley, Kimb and Tianc, (2017), studying innovation at the firm level, find that three years after the union election, the patent quantity, and quality of the U.S companies significantly decline. However, research focused on other advanced economies has shown more controversial findings. In particular, Chun et al. (2015), comparing labor unionized with non-labor unionized Korean manufacturers, find no significant difference in companies' R\&D expenditures. On the contrary, some studies in China demonstrate that unions encourage product innovation and R\&D investment (Fang and Ying, 2012; Tong et al., 2018). In the same line, Walsworth (2010), using longitudinal firm-level data, shows that the presence of a union in Canada has a small positive effect on the firm's ability to innovate new products.

Beyond the scope of developed countries, the analysis of the effect of unions on innovation has been minimal, particularly in Latin America. An exception is the work of Rios-Ávila (2017), who examines the relationship between unions and productivity in the manufacturing sector across six Latin-American countries: Argentina, Bolivia, Chile, Mexico, Uruguay, and Panamá. Four proxies of innovation are used as control variables: investment in $\mathrm{R} \& \mathrm{D}$, foreign company technology, product quality certification, and the introduction of new processes or products. The study finds that there is much heterogeneity across the countries of study. For instance, in Chile, a positive and significant effect of unionization is found on the introduction of new processes or products, while no effect is detected for the other three innovation measures. Similar results are observed for Argentina. On the contrary, a negative influence of unions on innovation is identified in Bolivia.

In line with previous studies that have shown conflicting results and heterogeneity among the countries of study, we are going to develop two competing hypotheses to take into account both positions.

\subsection{Unions have a negative effect on innovation.}

In general terms, the arguments that have been used to support the adverse effect of the unions on innovation can be organized in two groups: the arguments based on the effect of union on wages, and those pointing the influence of unions on management.

A fundamental part of the unions' work is to negotiate wages with employers in order to improve workers' economic wellbeing. In fact, in Chile, the evidence shows that most of the labor conflicts are motivated by wage negotiations (Observatorio de Huelgas Laborales, 2018). Innovation requires considerable investment, but its effect on companies economic indicators takes place, most of the times, in the medium-long term (Rouvinen, 2002). Therefore, companies can be discouraged from making this investment if they think its resulting benefits can be eventually expropriated by unions (Bradley, Kimb, and Tianc, 2017). Moreover, unions are characterized because they usually modify the distribution of wages and reduce inequality among workers (Sanhueza and Fernandez, 2015). For instance, Verma (2005:427) shows that the presence of a union reduces the likelihood of variable pay plans or individual payment incentives. Therefore, innovative workers can be motivated to migrate to non-union firms where individual economic rewards are more likely (Bradley, Kimb and Tianc, 2017).

Unions can also discourage innovation by limiting the management discretion to make the necessary changes within the company to advance toward this specific goal (Walsworth, 2010). For instance, unions can prevent management from implementing human resources policies that could foster a robust corporate culture to enhance employee motivation and commitment to innovation (Verma, 2005: 430). They also can put barriers to dismiss and intervene in the selection process, which can frustrate the plans of management to renew their staff in order to bolster innovation (Verma, 2005:423). Generally, this argument underlines that the existence of a union challenges the control in the workplace and thus makes more complicated the design, implement and assess the innovation plan. Based on the last arguments, our first hypothesis states: 
H1: Unions discourage firms' product, marketing, organizational and, process innovations in Chile.

\subsection{Unions have a positive effect on the different types of innovation.} On the opposite side, there are also arguments to sustain the positive effect of unions on innovation. The most popular argument is that unions have a "shock effect" on companies forcing or persuading management to adopt more efficient practices that they would have ignored otherwise, and that can improve innovation. This argument is based on the assumption that usually, companies do not have the necessary information or human ability to develop the most effective practices for improving innovation on their own. The fact that unions question management and the existent policies may encourage companies to improve and be more creative in order to maintain or increase firm' profits.

Verma (2005) distinguishes two effects within the "shock effect." First, there is the "pure shock" when unions produce better efficiency in the areas over which management has exclusive control, by the sole fact of existing or without engaging directly in this improvement. Such changes are initiated by management and respond to the idea that unions raise costs (usually increase employees' wages and thus, the cost of labor) and represent a threat; therefore, there is a need to be more efficient. Indeed, in Chile, studies show that union members enjoy a wage premium close to 20 percent (Landerretche, Lillo, and Puentes, 2013). Therefore, companies can be encouraged to compete based on innovation instead of competing based on a low-cost strategy (Walsworth, 2010; Fang and Ying, 2012). Second, there is a "voice effect," which is directly associated with unions' intervention. Unions can push management to change aspects of the production process that affect workers and propose creative solutions that can ultimately favor innovation. They also can help management in the design and implementation of their innovation plans, facilitating communication with employees, and providing feedback to management. There is empirical evidence that supports the idea that collaboration with unions is key to the success of organizational changes led by management (e.g., Martinez-Jurado, Moyano-Fuentes, Jerez-Gomez, 2014).

Besides the "shock effect," the positive effect of unions on innovation can be explained by the impact of unions' actions over the employees' behavior. Unions' actions favor union members' wages, and this can promote their commitment to innovation (Walsworth, 2010). Since innovation requires time to present any effect, companies need active engagement from employees. In that sense, unions provide workers the necessary guarantees to engage in higher-risk behaviors associated with innovation because they increase employment protection limiting dismissals and promoting senioritybased pay at the workplace (Bradley, Kimb and Tianc, 2017; Walsworth, 2010). Based on the recent arguments, our second hypothesis states:

H2: Unions favor firms' product, marketing, organizational, and process innovations in Chile.

\section{Unions in Chile: Background.}

Since the direction of the union effect on innovation is probably related to the context of analysis, this section is aimed to describe relevant features in the recent history of the Chilean unions and the labor legal framework.

Latin American unions have been characterized as playing a substantial role in the political arena. Chilean unions are not an exception, although this political influence has weakened during the last four decades. Their alliance with the communist and socialist political parties encouraged Chilean unions to increase mobilizations throughout the XX century and supported the political coalition that won the presidential election in 1970 with the promise of leading the country to a socialist economy. Despite their militancy, unions exerted a steady pressure over authorities to advance in the promised reforms (Angell, 1972).

The 1973 military coup deeply stroke unions. Following a period of prohibition and repression against the foremost union leaders, militaries authorized union activity, but under a completely different institutional framework. A set of reforms known as the Work Plan (Plan Laboral) (1979) adapted labor legislation to the neoliberal prescriptions that were implemented to install a market economy in Chile. Unions' prerogatives were largely restricted. For instance, collective bargaining was limited to the firm level; unions were prohibited from negotiating issues that "restrain or limit the faculty of employers to organize, lead or manage companies"; employers were allowed to replace workers and close workplace during strikes; workers were authorized to negotiate without the intervention of a union through the form of a "negotiation group". The explicit goal of this measure was to promote a decentralized and depoliticized system of employment relations which could guarantee employers enough flexibility to adapt the new macro-economic conditions (Winn, 2004)

The recuperation of democracy in 1990 did not bring the transformations that union leaders expected. Despite the strong relationship between the Central Unitaria de Trabajadores (CUT), the leading national union organization, and the political parties of the "Concertación," the center-left coalition in power from 1990 to 2009, labor regulation was minimally reformed. During the first decade, the CUT engaged with the governments in the promotion of a new national social pact between workers and businesses. As a result, a set of "Frame Agreements" was signed with the Confederation of Production and Commerce. However, apart from the increased minimum wage, scholars agree that these pacts were mostly a demonstration of goodwill (e.g., Sehnbruch, 2013; Frank, 2004). The first two labor reforms (1991 and 2001) did not consent to the core demands of the CUT, which is the extension of the collective bargaining to the branch level, the elimination of strikes' restrictions, and negotiation groups. The reform of 2016 eliminated the authorization of employers to replace workers during strikes, which were celebrated by unions as the first substantial change to the Labor Plan. However, other obligations, such as the creation of minimal services and "workers' adjustments", limited the impact of this measure (Arellano, 2015). 
The failure of its initial strategy led the CUT to increase mobilizations after 2000 . However, its political power has been relatively weakened by the internal divisions (Frias, 2008; Gutiérrez, 2016) and the overall low union density (Dirección del Trabajo, 2016b). This had not prevented unions from playing an essential role in the big and medium-size companies where unions are present in $65,3 \%$ and $20,5 \%$ cases, respectively (Dirección del Trabajo, 2016a). Moreover, unions assemble more than $20 \%$ of the workforce in economic branches such as transportation, financial intermediation, community services, fishing, mining, social services and health (Dirección del Trabajo, 2016b). In most of these branches, union activity has increased over the last decade (Observatorio de Huelgas Laborales, 2018; Gutiérrez and Gutiérrez, 2017).

\section{Sample, Variables, and Methodology}

\subsection{Sample.}

The data that we use to test our hypotheses come from the first and second Longitudinal Survey of Companies in Chile (published in the year 2009 and 2012, respectively). These surveys were jointly conducted by the National Institute of Statistics, the Ministry of Economy and the Microdata Center of the University of Chile. The primary purpose of the survey is to characterize the Chilean companies, to identify the determinants of business development as well as to measure the impact of different variables in the Total Productivity Factor. This survey is addressed to formal companies that develop productive, commercial and service activity, within the territorial limits of the country and whose sales level is higher than 2,56 US\$ during 2007 and 23.497,63 US $\$$ during $2009 .{ }^{5}$ The surveys were conducted by interviewing face-to-face, to the owners, partners or shareholders, and general managers of the companies. One of the strengths of the survey is its longitudinal condition and the fact that it has been replicated in several years (2009, 2012, 2015 and 2017). However, the design of some questions has varied from year to year, which has limited our period of study. Despite the existence of four surveys, we have to focus on the ones published in 2009 and 2012 since the ones from 2015 and 2017 had different questions regarding innovation and, they do not distinguish among the different types of innovation that we consider in this paper. How we proceeded to match the companies from the different surveys was the following: The 2009 survey presents the data for 10.213 companies while the 2012 survey presents the data for 7.062 companies. Since companies have an anonymous identifier that is maintained over time, we match both surveys using it, and we focus on the companies for which we have data in the two periods: this process reduces the number of companies to 2.667 .

\subsection{Variables.}

\subsubsection{Dependent Variables}

In an attempt to have a proxy for each of the different innovation types defined by the GII, we selected four questions from the questionnaire of the survey, and we convert this information into four dummy variables. Specifically, we have chosen the following questions from the 2012 survey:
Organizational innovation was proxied based on question F009: Have you carried out activities linked to the preparation and introduction of substantive improvements or new distribution methods? (linked to the logistics of the company)? With the resulting information, we created a dummy variable equal to 1 if the answer was yes and equal to 0 ; otherwise.

Product Innovation was proxied based on question F008: Has your company made any substantive improvement or created a new product in the goods/services it sells? With the resulting information, we created a dummy variable equal to 1 if the answer was yes and equal to 0 ; otherwise.

Process innovation was proxied based on question F007: Have you purchased machines, equipment and/or software for the introduction of new or significantly improved products or processes? With the resulting information, we created a dummy variable equal to 1 if the answer was yes and equal to 0 , otherwise.

Marketing innovation was proxied based on question F010: Have you made new marketing methods that involve significant changes in the design or packaging of a product, its positioning, its promotion or its pricing? With the resulting information, we created a dummy variable equal to 1 if the answer was yes and equal to 0 ; otherwise.

We considered that the resulting information from those questions is comparable with the one from the year 2009, question number 68 : In 2007, did your company introduce innovations? Answer in column 68.1 specifying the type of innovation: product, services, process, organizational and/or marketing. However, as this survey distinguishes between five different types of innovation, in order to capture the same information, we proceed to sum the product and the service innovation and create a dummy equal to 1 if the company innovate in product and/or in service, equal to 0 otherwise.

Since the objective of the paper is to analyze if the presence of unions favors or deter innovation and the effect in innovation is no immediate (Rouvinen, 2002), our dependent variables were measured in 2012 while our main independent variables were measured in 2009. However, because firms' current innovation (2012) could also be strongly affected by previous innovation activities (2009), since it establishes the propensity to innovate of a company (Geldes et al., 2016), we control for the existence of innovation practices in which companies have engaged in the previous period.

\subsubsection{Independent variables}

To measure the presence and strength of unions, we selected question number 92: How many unions exist in your company? and question 92.1: What was the percentage of affiliation? from the 2009 Survey. Based on the answers, the following variables were constructed:

\footnotetext{
${ }^{4}$ In particular, we used the ELE and ELE2 available at https://www.economia.gob.cl/category/estudios-encuestas/encuestas-y-bases-de-datos/encuesta-longitudinal-de-empresas-ele ${ }^{5}$ The conversion from UF to chilean pesos was done taken into account the UF value of march 2007 (18.383,35 chilean pesos) and the UF value of march 2009 (21.067,76 chilean pesos). After that, we used the exchange rate chilean peso - dollar of 8th october 2019.
} 
1. Union_Existence: Dummy variable that is equal to 1 if there is at least one union in the company, zero otherwise.

2. Union density: Percentage of unionization in each company (from 0 to 100$)$.

3. Union density levels: Dummy variable that distinguishes among the following different levels of union density. In order to analyze if the effect of unions is linear or not in innovation, we construct the same measure as Walsworth (2010), where Union Density None is our base category. Explicitly, we distinguish between the following levels of union density:

- Union Density None: Dummy variable equal to 1 if the percentage of unionization is equal to zero, 0 otherwise.

- Union Density low: Dummy variable equal to 1 if the percentage of unionization is $>0 \%$ and $20 \%$, equal to 0 otherwise.

- Union Density moderately low: Dummy variable equal to 1 if the percentage of unionization is $>20$ and $40 \%$, equal to 0 otherwise.

- Union density medium: Dummy variable equal to 1 if the percentage of unionization is $>40 \%$ and $60 \%$, equal to 0 otherwise.

- Union density high: Dummy variable equal to 1 if the percentage of unionization is $>60 \%$, equal to 0 otherwise.

\subsubsection{Control Variables}

Previous innovations: To control from previous innovation activities, we used the innovation dummies in the year 2009. These dummies are defined equal to 1 if the company has introduced this type of innovation, 0 if not. Since the propensity to innovate has been proved to be affect positively to the innovative performance (Geldes et al., 2017), we expect the introduction of innovative practices in the previous period to have a positive effect on the actual period.

Size: We control for company size using the logarithm of the number of employees per company. Based on Avermaete et al. (2003) and Maffini Gomes et al., (2009) we expect the company size to influence innovation.

Age: company age is measured as the difference between the year in which the company was founded and 2009. Based on Avermaete et al. (2003) we expect company age to present an effect on innovation.

Research and Development: Dummy variable equal to one if the firm invested in this period in research and development, and equal to zero otherwise. Following Geldes et al., (2017), we expect this variable to have a positive effect on innovation.
Subcontracting: Dummy variable equal to one if the company subcontracted at least any service in the period, equal to zero otherwise. Based on Beladi. and Mukherjee (2017), we expect this variable to have an effect on innovation.

CEO education: dummy variable equal to one if the CEO possess university education, zero otherwise. Based on Mo-Ahn et al. (2017), we expect CEO education to influence positively on the engagement of innovation practices.

Sector dummies: we add ten dummy sector variables to control for the fact that certain sectors are more prone to have high rates of innovation than others. The different dummies correspond to the following sectors: Mining, Manufacturing, Energy, Construction, Commerce, Hotels / Restaurants, Transportation, Real Estate, Finance, and Others. As the base category, we used the mining sector. Following Cefis and Orsenigo (2001), we expect that innovation to be affected by the different economic sectors.

\subsection{Methodology}

Since our objective is to evaluate the effect of the existence of unions and union density on the different types of innovation and they are binary variables, we use the following logit model:

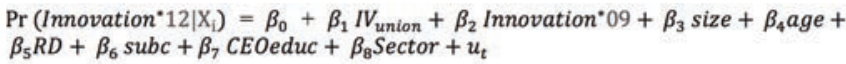

Where:

- $\quad$ Innovation ${ }^{\star} 12=$

Innov.in production,organization,marketing,and process in 2012.

- $\quad \mathrm{IV}_{\text {union }}=$ union_existence, union density and union density levels (union_low, union_moderately, union_medium and union_high).

- $\quad$ Innovation ${ }^{*} 09=$

- Innov.in production,organization,marketing and process in 2009.

- $\quad$ Sector $=$ Sector dummies.

\section{Descriptive Statistics and Results}

\subsection{Descriptive Statistics}

Table 1 presents the descriptive statistics of all the variables used in the regression. Regarding innovation variables, we can observe significant differences between the percentage of companies that perform different innovations and a growing trend in each one. Regarding the union variables, we can observe that just $15.3 \%$ of the companies have a union. 
Table 1: Descriptive Statistics

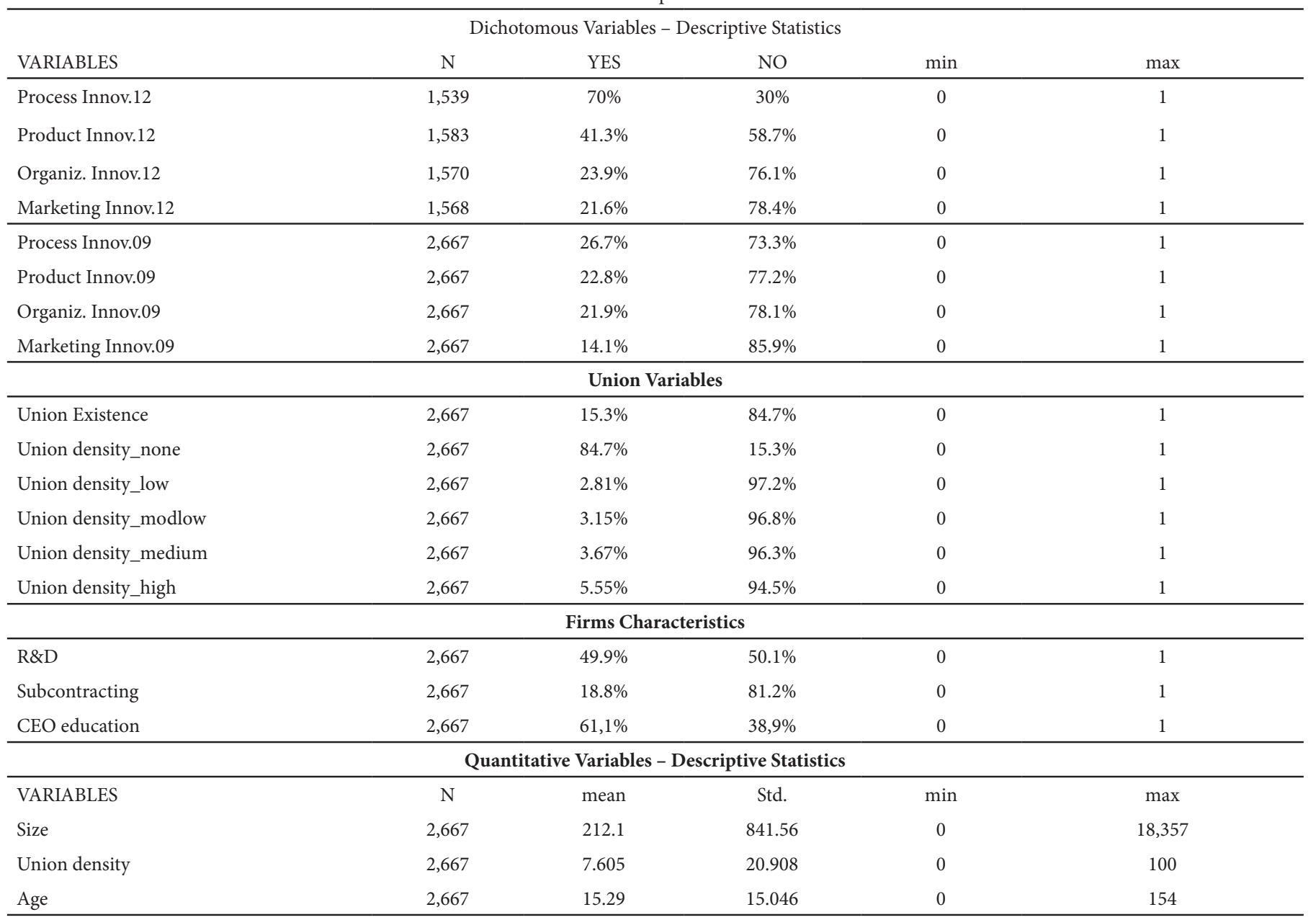

Table 2 shows the percentage of unions and union den-

sample. In this table, we can perceive many differences among sity distinguishing among the different sectors in the sectors.

Table 2: Descriptive Statistics by Sector

\begin{tabular}{lccc}
\hline & & Sector Dummies - Statistics & \\
\hline Variables & \# Firms & Union Existence (\%) & Unionization \\
\hline Agriculture & 158 & $9.50 \%$ & $3.31 \%$ \\
Mining & 130 & $20 \%$ & $12.89 \%$ \\
Manufacture & 357 & $29.13 \%$ & $16.32 \%$ \\
Energy & 78 & $48.72 \%$ & $31.26 \%$ \\
Construction & 261 & $7.66 \%$ & $3.49 \%$ \\
Commerce & 613 & $8.32 \%$ & $3.55 \%$ \\
Hotels/Restaurants & 270 & $7.78 \%$ & $2.80 \%$ \\
Transportation & 271 & $16.97 \%$ & $8.93 \%$ \\
Real Estate & 284 & $11.27 \%$ & $4.35 \%$ \\
Finance & 100 & $20 \%$ & $7.11 \%$ \\
Others & 145 & $23.35 \%$ & $11.09 \%$ \\
\hline Total & 2,667 & Mean= & Mean=7.60\% \\
\hline
\end{tabular}


Table 3 shows the percentage of companies that introduce the different types of innovations when they have unions vs. if they do not have them. As we can observe, for all the cases, the percentage of companies that introduce innovations is always $10 \%$ higher when there are unions.
Also, from this table, we can observe that, independently of the presence of unions, the percentage of companies that introduce the different innovation is increasing from the year 2009 to 2012 (except for the case of organizational innovation when there are unions).

Table 3: Descriptive Statistics by the existence of Unions vs the non-existence.

\begin{tabular}{lcc}
\hline & Union existence and Innovations & \\
\hline Variables & \% Innovation if Union_existence = 1 & \% Innovation if Union_existence = 0 \\
\hline Product Innov.12 & $49.25 \%$ & $39.20 \%$ \\
Process Innov.12 & $77.64 \%$ & $67.72 \%$ \\
Organiz. Innov.12 & $33.83 \%$ & $21.20 \%$ \\
Marketing Innov.12 & $27.11 \%$ & $20.06 \%$ \\
\hline Product Innov.09 & $34.64 \%$ & $20.66 \%$ \\
Process Innov.09 & $51.60 \%$ & $22.26 \%$ \\
Organiz. Innov.09 & $39.80 \%$ & $18.67 \%$ \\
Marketing Innov.09 & $25.80 \%$ & $11.95 \%$ \\
\hline
\end{tabular}

In Table 4, we observe the Pearson correlation among the variables of the study. As we can see, there are several variables with a positive and significant correlation. However, the ones that present a higher correlation (as is the case between the correlation between Union
Existence and Union density: 0.857 or between Union density and Union density High: $0.83 \%$ ) are not together in the regression because they are alternative IV. We do not think the other ones can imply a problem for the analysis.

Table 4: Matrix of Pearson Correlations

\begin{tabular}{|c|c|c|c|c|c|c|c|c|c|c|c|c|c|c|c|c|c|c|}
\hline (2) & (3) & (4) & (5) & (6) & (7) & (8) & (9) & (10) & (11) & (12) & (13) & (14) & (15) & (16) & (17) & (18) & (19) & (20) \\
\hline & & & & & & & & & & & & & & & & & & \\
\hline 1.000 & & & & & & & & & & & & & & & & & & \\
\hline $0.298^{*}$ & $0.405^{*}$ & 1.000 & & & & & & & & & & & & & & & & \\
\hline $0.187^{*}$ & $0.166^{*}$ & $0.171^{*}$ & 1.000 & & & & & & & & & & & & & & & \\
\hline $0.142^{*}$ & $0.114^{*}$ & 0.065 & $0.415^{*}$ & 1.000 & & & & & & & & & & & & & & \\
\hline $0.083^{*}$ & $0.121^{*}$ & $0.070^{*}$ & $0.120^{*}$ & $0.238^{*}$ & $0.184^{*}$ & $0.143^{*}$ & 1.000 & & & & & & & & & & & \\
\hline $0.084^{*}$ & $0.110^{*}$ & 0.051 & $0.098^{*}$ & $0.211^{*}$ & $0.167^{*}$ & $0.116^{*}$ & $0.857^{*}$ & 1.000 & & & & & & & & & & \\
\hline$-0.083^{*}$ & $-0.121^{*}$ & $-0.070^{*}$ & $-0.120^{*}$ & $-0.238^{*}$ & $-0.184^{\star}$ & $-0.143^{*}$ & -1.000 & $-0.857^{*}$ & 1.000 & & & & & & & & & \\
\hline 0.016 & 0.032 & -0.001 & 0.024 & $0.101^{*}$ & $0.050^{*}$ & 0.045 & $0.395^{*}$ & 0.012 & $-0.395^{*}$ & 1.000 & & & & & & & & \\
\hline 0.014 & -0.007 & 0.048 & $0.066^{*}$ & $0.071^{*}$ & 0.050 & $0.063^{*}$ & $0.425^{*}$ & $0.212^{*}$ & $-0.425^{*}$ & -0.030 & 1.000 & & & & & & & \\
\hline 0.055 & $0.133^{*}$ & $0.073^{*}$ & $0.079^{*}$ & $0.112^{\star}$ & $0.123^{*}$ & $0.093^{*}$ & $0.460^{*}$ & $0.414^{*}$ & $-0.460^{*}$ & -0.033 & -0.035 & 1.000 & & & & & & \\
\hline $0.084^{*}$ & $0.109^{*}$ & $0.076^{*}$ & $0.125^{*}$ & $0.281^{*}$ & $0.216^{*}$ & $0.147^{*}$ & $0.350^{*}$ & $0.292^{*}$ & $-0.350^{*}$ & $0.101^{*}$ & $0.182^{*}$ & $0.176^{*}$ & $0.181^{*}$ & $0.468^{*}$ & $0.160^{*}$ & $-0.243^{*}$ & 1.000 & \\
\hline $0.106^{*}$ & $0.104^{*}$ & $0.068^{*}$ & $0.140^{*}$ & $0.231^{*}$ & $0.195^{*}$ & $0.114^{*}$ & $0.233^{*}$ & $0.221^{*}$ & $-0.233^{*}$ & 0.049 & $0.100^{*}$ & $0.123^{*}$ & $0.153^{*}$ & $0.413^{*}$ & $0.084^{*}$ & $-0.184^{*}$ & $0.281^{*}$ & 1.000 \\
\hline
\end{tabular}

\subsection{Results}

Our estimates of the determinants of innovation are presented in Table 5 (union existence as the independent variable), Table 6 (union density as the independent variable) and Table 7 (union density levels as independent variables). In each table, we can observe the regressions of the four types of innovations, where model 1 present the regression with the control variables and model 2 adds to the existing regression of the independent variable. In Table 5, the coefficient of union existence is negative and no significant for every type of innovation. In Table 6, the coefficient of union density is negative for the product, marketing, and process innovation but not significant. The coefficient of organizational innovation is positive but also no significant. Therefore, neither the results of table 5 nor the ones in table 6 support any of our hypotheses. 
Table 5. Logit - Union Existence

\begin{tabular}{|c|c|c|c|c|c|c|c|c|}
\hline \multirow[b]{2}{*}{ VARIABLES } & \multicolumn{2}{|c|}{ Product Innovation } & \multicolumn{2}{|c|}{ Organization Innovation } & \multicolumn{2}{|c|}{ Marketing Innovation } & \multicolumn{2}{|c|}{ Process Innovation } \\
\hline & (1) & (2) & (1) & (2) & (1) & $(2)$ & (1) & (2) \\
\hline \multirow[t]{2}{*}{ Union Existence } & & -0.131 & & -0.117 & & -0.0435 & & -0.0549 \\
\hline & & $(0.171)$ & & $(0.183)$ & & $(0.193)$ & & $(0.188)$ \\
\hline \multirow[t]{2}{*}{ Product Innov.09 } & $0.408^{\star * *}$ & $0.406^{* * *}$ & $0.353^{\star *}$ & $0.350^{* *}$ & $0.461^{* * *}$ & $0.461^{\star * *}$ & 0.0666 & 0.0651 \\
\hline & $(0.137)$ & $(0.137)$ & $(0.157)$ & $(0.157)$ & $(0.163)$ & $(0.163)$ & $(0.153)$ & $(0.153)$ \\
\hline \multirow[t]{2}{*}{ Process Innov.09 } & 0.200 & 0.201 & -0.0531 & -0.0511 & -0.100 & -0.100 & $0.307^{\star}$ & $0.308^{\star}$ \\
\hline & $(0.144)$ & $(0.144)$ & $(0.172)$ & $(0.172)$ & $(0.174)$ & $(0.174)$ & $(0.160)$ & $(0.160)$ \\
\hline \multirow[t]{2}{*}{ Market. Innov.09 } & 0.182 & 0.180 & $0.461^{\star *}$ & $0.457^{\star *}$ & $0.550^{* * *}$ & $0.548^{\star * *}$ & -0.0788 & -0.0799 \\
\hline & $(0.166)$ & $(0.165)$ & $(0.182)$ & $(0.181)$ & $(0.184)$ & $(0.184)$ & $(0.180)$ & $(0.180)$ \\
\hline \multirow[t]{2}{*}{ Organiz. Innov.09 } & 0.106 & 0.104 & 0.0505 & 0.0487 & -0.163 & -0.164 & -0.0312 & -0.0320 \\
\hline & $(0.158)$ & $(0.158)$ & $(0.188)$ & $(0.188)$ & $(0.193)$ & $(0.193)$ & $(0.168)$ & $(0.168)$ \\
\hline \multirow[t]{2}{*}{ Size } & 0.0171 & 0.0310 & $0.167^{\star * *}$ & $0.181^{\star * *}$ & $0.108^{\star *}$ & $0.113^{\star *}$ & $0.101^{\star *}$ & $0.107^{* *}$ \\
\hline & $(0.0355)$ & $(0.0396)$ & $(0.0397)$ & $(0.0455)$ & $(0.0425)$ & $(0.0482)$ & $(0.0398)$ & $(0.0436)$ \\
\hline \multirow[t]{2}{*}{ Age } & 0.00371 & 0.00400 & 0.00397 & 0.00422 & -0.00437 & -0.00427 & 0.00232 & 0.00244 \\
\hline & $(0.00337)$ & $(0.00339)$ & $(0.00388)$ & $(0.00389)$ & $(0.00439)$ & $(0.00440)$ & $(0.00407)$ & $(0.00408)$ \\
\hline \multirow[t]{2}{*}{$\mathrm{R} \& \mathrm{D}$} & -0.0995 & -0.0989 & -0.107 & -0.106 & $0.245^{\star}$ & $0.246^{*}$ & $-0.341^{\star * *}$ & $-0.341^{\star * *}$ \\
\hline & $(0.121)$ & $(0.121)$ & $(0.142)$ & $(0.142)$ & $(0.147)$ & $(0.147)$ & $(0.126)$ & $(0.126)$ \\
\hline \multirow[t]{2}{*}{ Subcontracting } & 0.147 & 0.161 & 0.126 & 0.136 & $0.367^{\star *}$ & $0.372^{\star *}$ & 0.0208 & 0.0264 \\
\hline & $(0.143)$ & $(0.144)$ & $(0.155)$ & $(0.157)$ & $(0.166)$ & $(0.167)$ & $(0.157)$ & $(0.159)$ \\
\hline \multirow[t]{2}{*}{ CEO_edu } & $0.352^{\star * *}$ & $0.352^{* * *}$ & 0.264 & 0.265 & 0.268 & 0.268 & $-0.255^{\star}$ & $-0.255^{\star}$ \\
\hline & $(0.135)$ & $(0.135)$ & $(0.163)$ & $(0.163)$ & $(0.165)$ & $(0.165)$ & $(0.145)$ & $(0.145)$ \\
\hline Sector Dummies & YES & YES & YES & YES & YES & YES & YES & -0.440 \\
\hline \multirow[t]{2}{*}{ Constant } & $-1.169^{* * *}$ & $-1.190^{\star * *}$ & $-2.697^{* * *}$ & $-2.719^{\star * *}$ & $-2.652^{* * *}$ & $-2.661^{\star * *}$ & $1.223^{\star * *}$ & $1.216^{* * *}$ \\
\hline & $(0.304)$ & $(0.306)$ & $(0.404)$ & $(0.407)$ & $(0.429)$ & $(0.432)$ & $(0.356)$ & $(0.357)$ \\
\hline Observations & 1,489 & 1,489 & 1,481 & 1,481 & 1,476 & 1,476 & 1,448 & 1,448 \\
\hline Pseudo R-squared & 0.0677 & 0.0680 & 0.0869 & 0.0871 & 0.0916 & 0.0917 & 0.0373 & 0.0374 \\
\hline
\end{tabular}


Table 6. Logit - Union Density

\begin{tabular}{|c|c|c|c|c|c|c|c|c|}
\hline \multirow[b]{2}{*}{ VARIABLES } & \multicolumn{2}{|c|}{ Product Innovation } & \multicolumn{2}{|c|}{ Organization Innovation } & \multicolumn{2}{|c|}{ Marketing Innovation } & \multicolumn{2}{|c|}{ Process Innovation } \\
\hline & (1) & (2) & (1) & (2) & (1) & (2) & (1) & $(2)$ \\
\hline Union Density & & $(0.00278)$ & & $(0.00292)$ & & $(0.00313)$ & & $(0.00309)$ \\
\hline Product Innov.09 & $0.408^{* * *}$ & $0.408^{* * *}$ & $0.353^{\star \star}$ & $0.353^{\star *}$ & $0.461^{\star * *}$ & $0.461^{\star * *}$ & 0.0666 & 0.0641 \\
\hline Process Innov.09 & $(0.144)$ & $(0.144)$ & $(0.172)$ & $(0.172)$ & $(0.174)$ & $(0.174)$ & $(0.160)$ & $(0.160)$ \\
\hline \multirow[t]{2}{*}{ Market. Innov. 09} & 0.182 & 0.182 & $0.461^{\star *}$ & $0.462^{\star *}$ & $0.550^{* * *}$ & $0.549^{* * *}$ & -0.0788 & -0.0829 \\
\hline & $(0.166)$ & $(0.166)$ & $(0.182)$ & $(0.182)$ & $(0.184)$ & $(0.184)$ & $(0.180)$ & $(0.180)$ \\
\hline Organiz. Innov.09 & 0.106 & 0.106 & 0.0505 & 0.0504 & -0.163 & -0.163 & -0.0312 & -0.0293 \\
\hline \multirow[t]{2}{*}{ Age } & 0.00371 & 0.00373 & 0.00397 & 0.00395 & -0.00437 & -0.00431 & 0.00232 & 0.00260 \\
\hline & $(0.00337)$ & $(0.00339)$ & $(0.00388)$ & $(0.00389)$ & $(0.00439)$ & $(0.00438)$ & $(0.00407)$ & $(0.00406)$ \\
\hline \multirow[t]{2}{*}{$\mathrm{R} \& \mathrm{D}$} & -0.0995 & -0.0994 & -0.107 & -0.107 & $0.245^{\star}$ & $0.246^{*}$ & $-0.341^{\star * \star}$ & $-0.341^{\star * *}$ \\
\hline & $(0.121)$ & $(0.121)$ & $(0.142)$ & $(0.142)$ & $(0.147)$ & $(0.147)$ & $(0.126)$ & $(0.126)$ \\
\hline \multirow[t]{2}{*}{ Subcontracting } & 0.147 & 0.148 & 0.126 & 0.125 & $0.367^{\star \star}$ & $0.368^{* *}$ & 0.0208 & 0.0284 \\
\hline & $(0.143)$ & $(0.143)$ & $(0.155)$ & $(0.156)$ & $(0.166)$ & $(0.166)$ & $(0.157)$ & $(0.157)$ \\
\hline CEO_edu & $0.352^{\star * *}$ & $0.352^{\star * *}$ & 0.264 & 0.263 & 0.268 & 0.269 & $-0.255^{*}$ & $-0.252^{*}$ \\
\hline \multirow[t]{2}{*}{ Sector Dummies } & YES & YES & YES & YES & YES & YES & YES & -0.454 \\
\hline & $(0.349)$ & $(0.349)$ & $(0.487)$ & $(0.487)$ & $(0.479)$ & $(0.479)$ & $(0.405)$ & $(0.404)$ \\
\hline
\end{tabular}


Table 7. Logit - Union Density Level

\begin{tabular}{|c|c|c|c|c|c|c|c|c|}
\hline \multirow[b]{2}{*}{ VARIABLES } & \multicolumn{2}{|c|}{ Product Innovation } & \multicolumn{2}{|c|}{ Organization Innovation } & \multicolumn{2}{|c|}{ Marketing Innovation } & \multicolumn{2}{|c|}{ Process Innovation } \\
\hline & (1) & (2) & (1) & (2) & (1) & (2) & (1) & (2) \\
\hline \multirow[t]{2}{*}{ UDensity_low } & & -0.0128 & & -0.242 & & $-0.663^{*}$ & & 0.229 \\
\hline & & $(0.320)$ & & $(0.322)$ & & $(0.389)$ & & $(0.379)$ \\
\hline \multirow[t]{2}{*}{ UDensity_modlow } & & -0.387 & & $-0.904^{\star * *}$ & & 0.00179 & & -0.192 \\
\hline & & $(0.279)$ & & $(0.324)$ & & $(0.307)$ & & $(0.311)$ \\
\hline \multirow[t]{2}{*}{ UDensity_medium } & & -0.0355 & & $0.524^{*}$ & & 0.209 & & -0.265 \\
\hline & & $(0.272)$ & & $(0.275)$ & & $(0.288)$ & & $(0.301)$ \\
\hline \multirow[t]{2}{*}{ UDensity_high } & & -0.00393 & & -0.180 & & -0.285 & & -0.144 \\
\hline & & $(0.238)$ & & $(0.259)$ & & $(0.283)$ & & $(0.269)$ \\
\hline \multirow[t]{2}{*}{ Product Innov.09 } & $0.408^{\star * *}$ & $0.413^{* * *}$ & $0.353^{\star *}$ & $0.369^{* *}$ & $0.461^{* * *}$ & $0.453^{\star * *}$ & 0.0666 & 0.0692 \\
\hline & $(0.137)$ & $(0.137)$ & $(0.157)$ & $(0.157)$ & $(0.163)$ & $(0.163)$ & $(0.153)$ & $(0.153)$ \\
\hline \multirow[t]{2}{*}{ Process Innov.09 } & 0.200 & 0.191 & -0.0531 & -0.0566 & -0.100 & -0.0797 & $0.307^{\star}$ & $0.297^{\star}$ \\
\hline & $(0.144)$ & $(0.145)$ & $(0.172)$ & $(0.171)$ & $(0.174)$ & $(0.174)$ & $(0.160)$ & $(0.160)$ \\
\hline \multirow[t]{2}{*}{ Market. Innov.09 } & 0.182 & 0.181 & $0.461^{\star *}$ & $0.476^{* * *}$ & $0.550^{* * *}$ & $0.555^{* * *}$ & -0.0788 & -0.0868 \\
\hline & $(0.166)$ & $(0.166)$ & $(0.182)$ & $(0.182)$ & $(0.184)$ & $(0.184)$ & $(0.180)$ & $(0.180)$ \\
\hline \multirow[t]{2}{*}{ Organiz. Innov.09 } & 0.106 & 0.101 & 0.0505 & 0.0176 & -0.163 & -0.182 & -0.0312 & -0.0245 \\
\hline & $(0.158)$ & $(0.159)$ & $(0.188)$ & $(0.187)$ & $(0.193)$ & $(0.192)$ & $(0.168)$ & $(0.168)$ \\
\hline \multirow[t]{2}{*}{ Size } & 0.0171 & 0.0271 & $0.167^{\star * *}$ & $0.191^{\star * *}$ & $0.108^{* *}$ & $0.127^{\star * *}$ & $0.101^{\star *}$ & $0.112^{\star * \star}$ \\
\hline & $(0.0355)$ & $(0.0392)$ & $(0.0397)$ & $(0.0458)$ & $(0.0425)$ & $(0.0484)$ & $(0.0398)$ & $(0.0432)$ \\
\hline \multirow[t]{2}{*}{ Age } & 0.00371 & 0.00388 & 0.00397 & 0.00384 & -0.00437 & -0.00445 & 0.00232 & 0.00271 \\
\hline & $(0.00337)$ & $(0.00339)$ & $(0.00388)$ & $(0.00412)$ & $(0.00439)$ & $(0.00445)$ & $(0.00407)$ & $(0.00405)$ \\
\hline \multirow[t]{2}{*}{$\mathrm{R} \& \mathrm{D}$} & -0.0995 & -0.0988 & -0.107 & -0.111 & $0.245^{*}$ & 0.237 & $-0.341^{\star * *}$ & $-0.337^{* * *}$ \\
\hline & $(0.121)$ & $(0.120)$ & $(0.142)$ & $(0.142)$ & $(0.147)$ & $(0.147)$ & $(0.126)$ & $(0.127)$ \\
\hline \multirow[t]{2}{*}{ Subcontracting } & 0.147 & 0.171 & 0.126 & 0.146 & $0.367^{* *}$ & $0.363^{* *}$ & 0.0208 & 0.0427 \\
\hline & $(0.143)$ & $(0.144)$ & $(0.155)$ & $(0.157)$ & $(0.166)$ & $(0.168)$ & $(0.157)$ & $(0.159)$ \\
\hline \multirow[t]{2}{*}{ CEO edu } & $0.352^{* * *}$ & $0.350^{* * *}$ & 0.264 & 0.254 & 0.268 & 0.267 & $-0.255^{\star}$ & $-0.249^{*}$ \\
\hline & $(0.135)$ & $(0.136)$ & $(0.163)$ & $(0.164)$ & $(0.165)$ & $(0.165)$ & $(0.145)$ & $(0.145)$ \\
\hline Sector dummies & YES & YES & YES & YES & YES & YES & YES & $(0.353)$ \\
\hline \multirow[t]{3}{*}{ Constant } & $-1.169^{* * *}$ & $-1.199^{* * *}$ & $-2.697^{\star * *}$ & $-2.794^{* * *}$ & $-2.652^{* * *}$ & $-2.676^{* * *}$ & $1.223^{* * *}$ & -0.639 \\
\hline & $(0.304)$ & $(0.305)$ & $(0.404)$ & $(0.425)$ & $(0.429)$ & $(0.438)$ & $(0.356)$ & $(0.444)$ \\
\hline & & & & & & & & $-0.865^{\star *}$ \\
\hline Observations & 1,489 & 1,489 & 1,481 & 1,481 & 1,476 & 1,476 & 1,448 & $(0.361)$ \\
\hline \multirow[t]{2}{*}{ Pseudo R-squared } & 0.0387 & 0.0687 & 0.0387 & 0.0960 & 0.0387 & 0.0948 & 0.0387 & $-0.827^{\star *}$ \\
\hline & & & & & & & & $(0.337)$ \\
\hline
\end{tabular}

Robust standard errors in parentheses

${ }^{* * *} \mathrm{p}<0.01,{ }^{* *} \mathrm{p}<0.05,{ }^{*} \mathrm{p}<0.1$ 
However, table 7 shows more precise results. In this table, union density is segmented into five groups. The dummy variable identifying companies with null union density acts as the reference group for the remaining four union density level variables. As is observed, for the product, and process innovation the coefficients for every union density level are no significant. However, for organizational innovation, the coefficient for union density moderately low is negative and significant at the 0.01 level while the coefficient for union density medium is positive and significant at the 0.1 level. In other words, compared to companies with no union presence, a moderately low level of union density (> 20\% - 40\%) restricts a company's capacity to innovate in organizational aspects, whereas the medium level of union density (> 40\% - 60\%)) promote this type of innovation. The coefficients for the other two extreme union density levels (low and high union density) are not statistically significant for this type of innovation. For marketing innovation, a significant negative effect at the 0.01 level is observed for companies with low union density (20). Meanwhile, companies with higher levels of union density do not show significant results. All these results are supported using the Probit model ${ }^{6}$

\section{Conclusion and Discussion}

The primary objective of this paper was to analyze the effect of unions on innovation in the Chilean context. Our results do not support completely any of the two competing hypotheses, instead they suggest both are acceptable because the direction and significance of union effect depend on the type of innovation and the union density level.

Two interesting questions arise from these findings and demand further research in the field. First, why is the union' effect significant on the organizational and marketing innovations and is not on the product and the process innovations? The particularities of the Chilean context could help to understand this puzzle. As it was mentioned in the background section, the legislation radically limits the scope of negotiation. In practice, collective bargaining is restrained from wasting adjustment, working time, workers' benefits and other superficial aspects of the labor process (Dirección del Trabajo, 2016a). Moreover, chilean union leaders rarely count with basic business or management training, therefore they have difficulties to negotiate in equal conditions with managers complicate aspects of production. In consequence, any union intervention in favor or against innovation will probably refer to organizational aspects.

On the other hand, the adverse effect of unions on marketing innovation may be explained by the unions' effect on wages. In general terms, companies that feel threatened and that face any level of uncertainty, tend to reduce investments in intangible assets, such as marketing, because their effects are not immediate and a priori do not affect the company production (Stein, 2005). In the same line, it could be that Chilean companies may be motivated to cut off or reduce the investment in marketing innovation when they fear unions can eventually expropriate the fruit of this investment. No doubt, it is easier and less costly for companies to intervene in this area to compensate unions' effect on wage compared with reducing the process or product innovation that can put at risk their competitive advantage. Further research should explain why this effect became statistically insignificant for companies with more than $20 \%$ of union density.

The second question refers to the differences that were found between the coefficients of the four union density levels. On the one hand, the effect of union on organizational innovation was not significant in companies with the lowest union density. This may be explained because unions in these cases are too weak to force management to modify its practices, either to stop an innovation plan or to promote one. The effect on organizational innovation would become visible when unions count with the support of a more relevant part of the employees and thus when they can challenge management. On the other hand, the effect on the organizational innovation revealed to be negative when union density is between $20 \%$ and $40 \%$, positive when is between $40 \%$ and $60 \%$, and negative but not significant when is higher than $60 \%$. This suggests that organizational innovation does not respond linearly to union strength. For instance, powerful middle unions may be more motivated to collaborate with management in the implementation of an innovation plan than moderately low powerful unions because the first have probably satisfied more basic needs and have more chances to turn this plan in favor of workers. Instead, strongest unions could be interested in pursuing more radical changes at the workplace that are not necessarily favorable to management's innovation's plans because they have the resources to do so. In other words, whether unions and management collaborate for fostering innovation depend on multiple factors, union density could be just one of them. Further research is needed to identify the other factors at stake. A key aspect to consider in this research should be the power of unions in different economic branches. Regardless of the union density, chilean unions in economic branches such mining, that are strategic for the country, have more chances to force management to negotiate and, thus, to affect innovation.

Finally, we consider essential to point out the implication of our findings to the GII. Although their role in innovative activities depends on multiple factors, unions are an important element of the national economy in countries with high union density or where unions play a political role. This is the case of many Latin America nations. Our findings confirm that, under certain conditions, unions can generate inefficiency inside the organization and divert companies from innovating, but they can also be a key ally for management to promote such initiatives. In this sense, in our opinion, the GII should consider this aspect in its analysis. We are not suggesting that the GII should encourage countries to promote unions for increasing firms' competitiveness, but that it should consider the existence of these organizations as a relevant parameter in the design and implementation of innovation policies.

\footnotetext{
${ }^{6}$ For further information regarding the tables, please contact the corresponding author.
} 
This paper presents two main limitations: First, our sample is not representative; therefore, our results cannot be generalized to the whole population. Second, our study considers just two periods, limiting the use of econometric models that can capture better the specificities of the data. Further research should be focused on capturing better and more detailed data to complement the presented results.

\section{References}

Angell, A. (1972). Politics and the Labour Movement in Chile. 1St Edition. Oxford: Oxford University Press.

Angus, C., Cozzi, G. \& Furukawa, Y. (2016). Unions, innovation and cross-country wage inequality, Journal of Economic Dynamics and Control, 64(C): 104-118. DOI: 10.1016/j.jedc.2015.12.004

Arellano, A. (2015). Reforma Laboral: El proyecto es un retroceso para el mundo sindical. Chipre Chile. Available online in: https:// ciperchile.cl/2015/09/29/reforma-laboral-el-proyecto-es-un-retroceso-para-el-mundo-sindical/

Avermaete, T., Viaene, J., Morgan, E.J., Crawford, N. (2003) Determinants of innovation in small food firms. European Journal of Innovation Management, 6 (1);8-17. https://doi. org/10.1108/14601060310459163

Bradley, D; Kimb, K.; and Tianc, X. (2017). Do unions affect innovation? Management Science, 63 (7): 2049-2395 https://doi.org/10.1287/ mnsc.2015.2414

Beladi, H. and Mukherjee, A. (2017). Union bargaining power, subcontracting and innovation. Journal of Economic Behavior and Organization, 137:90-104. https://doi.org/10.1016/j.jebo.2017.02.013

Cefis, E. and Orsenigo, L. (2001). The persistence of innovative activities: A cross-countries and cross-sectors comparative analysis. Research Policy, 30 (7):1139-1158. https://doi.org/10.1016/S00487333(00)00139-6

Chu, A. Cozzi, G. and Furukawa, Y. (2016). Unions, innovation and cross-country wage inequality. Journal of Economic Dynamic and Control, 64: 104-118. DOI: 10.1016/j.jedc.2015.12.004

Chun, D., Chung, Y., Woo, Ch., Seo, H. and Ko, H. (2015). Labor Union Effects on Innovation and Commercialization Productivity: An Integrated Propensity Score Matching and Two-Stage Data Envelopment Analysis. Sustainability, 7: 5120-5138. doi:10.3390/su7055120

Dirección del Trabajo, Gobierno de Chile, 2016a. Encuesta Laboral (ENCLA) 2014. https://www.dt.gob.cl/portal/1629/w3-propertyvalue-22780.html. Last visited 11-02-2019.

Dirección del Trabajo, Gobierno de Chile. 2016b. Compendio estadístico. https://www.dt.gob.cl/portal/1629/w3-propertyvalue-22777. html. Last visited 11-02-2019.
Fang, T. and Ying G. (2012). Unions and firm innovation in China: Synergy or strife? China Economic Review, 23 (1):170-180. https://doi. org/10.1016/j.chieco.2011.09.001

Frank, V. (2004). Politics without Policy: The Failure of Social Concertation in Democratic Chile, 1990-2000. In Victims of the Chilean Miracle. Workers and Neoliberalism in the Pinochet Era, 1973-2002. Durham and London: Duke University Press, 2004.

Frías Fernández, P. (2008). Los Desafíos Del Sindicalismo en los Inicios del Siglo XXI. Becas de Investigación. Buenos Aires, Argentina: CLACSO.

Geldes, C., Felzensztein, C. and Palacios-Fenech, J., 2017 Technological and non-technological innovations, performance and propensity to innovate across industries: The Case of an emerging economy. Industrial Marketing Management, 61:55-66.

Geldes, C. and Felzensztein, C. (2013). Marketing Innovations in the agribusiness sector. Academia Revista Latinoamericana de Administración, 26 (1):108-138. DOI: 10.1108/ARLA-05-2013-0042

Geldes, C., Felzensztein, C. and Palacios-Fenech, J., (2017b). Technological and non-technological innovations, performance and propensity to innovate across industries: The Case of an Emerging Economy. Industrial Marketing Management, 61:55-66. https://doi. org/10.1016/j.indmarman.2016.10.010

Gutiérrez, F.(2016). “Sindicatos sin socios, pero representativos? Ideologías de la representatividad sindical en Chile”. Revista Polis, 43. http://polis.revues.org/11749

Gutiérrez, F. y Gutiérrrez, I. (2017). Movilización legal: una estrategia sindical con efectos ambivalentes. Izquierdas, 36: 200-221. doi:10.11 77/0730888401028002002.

Landerretche, O; Lillo Bustos, N. and Puentes, E. (2013). The Union Effect on Wages in Chile: A Two-Stage Approach Using Panel Data. LABOUR,. 27, (2): 164-191. doi/10.1111/labr.12011.

Maffini Gomes, C., Kruglianskas, I., Luciane Sherer, F. (2009). Company Size Effect in Innovative Performance. Journal of Technology Management and Innovation, 4 (4). http://dx.doi.org/10.4067/S071827242009000400002

Martínez-Jurado, P.J., Moyano-Fuentesa, J. and Jerez-Gómez, P. (2014). Human resource management in Lean Production adoption and implementation processes: Success factors in the aeronautics industry. BRQ Business Research Quarterly, 17(1): 47-68. https://doi. org/10.1016/j.cede.2013.06.004

Mo Ahn, J., Minshall, T. and Mortara, L., (2017). Understanding the human side of openness: the fit between open innovation modes and CEO characteristics. R\&D Management, 47 (5): 727-740. https://doi. org/10.1111/radm.12264 
Murillo, M.V. (2001). Labor Unions, Partisan Coalitions, and Market Reforms in Latin America. New York: Cambridge University Press, 2001.

Observatorio de Huelgas Laborales (UAH-COES). 2018. Informe de Huelgas Laborales 2017. Disponible en http://www.coes.cl/observatorio-de-huelgas-laborales/

OECD,(2006), Organization for Economic Cooperation and Development). Guidelines for Collecting and Interpreting Innovation Data - The Oslo Manual, Paris: OECD.

Rios-Ávila, F. (2017). Unions and Economic Performance in Developing Countries: Case Studies from Latin America. Ecos de Economía, 21(44): 4-36. https://doi.org/10.17230/ecos.2017.44.1

Rouvinen, P. (2002). R\&D Productivity Dynamics: Causality, Lags, and "Dry Holes." Journal of Applied Economics, 5(1), 123-15. https:// doi.org/10.1080/15140326.2002.12040573

Sanhueza, C. and Fernandez, E. (2015). The Impact of Unions over the Income Distribution: Analysis with Panel Data. Working paper. https://lacer.lacea.org/bitstream/handle/123456789/53081/lacea2015_ impact_trade_unions.pdf? sequence $=1$. Last visited: 07-03-2019
Sehnbruch, Kirsten, and Peter M. Siavelis, (2013). Democratic Chile: The Politics and Policies of a Historic Coalition, 1990-2010. Boulder, Colorado: Lynne Rienner Publishers, Inc., 2013.

Tong, L.; Liu, N.; Zhang,M.; Wang, L. (2018). Employee Protection and Corporate Innovation: Empirical Evidence from China. Journal of Business Ethics, 153 (2):569-589. DOI: 10.1007/s10551-016-3412-3

Verma, A. (2005). What do Unions do to the Workplace? Union Effects on Management and HRM Policies. Journal of Labor Research, 26(3): 415-449. https://doi.org/10.1007/s12122-005-1013-5

Walsworth, S. (2010). What Do Unions Do to Innovation? An Empirical Examination of the Canadian Private Sector. Relations Industrielles, 65(4): 543-561. https:// doi.org/10.7202/045585ar

Winn, P. (2004). Victims of the Chilean Miracle. Workers and Neoliberalism in the Pinochet Era, 1973-2002. Durham and London: Duke University Press.

Zapata, F. (2001). ¿Crisis en el sindicalismo en América Latina?. Cuadernos del Cendes, 18 (47): 1-24. 
